University of Michigan Law School

University of Michigan Law School Scholarship Repository

\title{
Educational Equality for Children with Disabilities: The 2016 Term Cases
}

\author{
Samuel R. Bagenstos \\ University of Michigan Law School, sambagen@umich.edu
}

Available at: https://repository.law.umich.edu/book_chapters/112

Follow this and additional works at: https://repository.law.umich.edu/book_chapters

Part of the Constitutional Law Commons, Disability Law Commons, Education Law Commons, Juvenile Law Commons, Legislation Commons, and the Supreme Court of the United States Commons

\section{Publication Information \& Recommended Citation}

Bagenstos, Samuel. "Educational Equality for Children with Disabilities: The 2016 Term Cases." In American Constitution Society Supreme Court Review 2016-2017, edited by S. D. Schwinn, 17-48. American Constitution Society, 2017.

This Book Chapter is brought to you for free and open access by the Faculty Scholarship at University of Michigan Law School Scholarship Repository. It has been accepted for inclusion in Book Chapters by an authorized administrator of University of Michigan Law School Scholarship Repository. For more information, please contact mlaw.repository@umich.edu. 


\section{Educational Equality for Children with Disabilities: The 2016 Term Cases}

\section{Samuel R. Bagenstos*}

\section{Introduction: Equality versus Adequacy in the Education of Disabled Children}

One of the most longstanding debates in educational policy pits the goal of equality against the goal of adequacy: Should we aim to guarantee that all children receive an equal education? Or simply that they all receive an adequate education?

The debate is vexing in part because there are many ways to specify "equality" and "adequacy." Are we talking about equality of inputs (which inputs?), equality of opportunity (to achieve what?), or equality of results (which results?)? Douglas Rae and his colleagues famously argued that there are no fewer than 108 structurally distinct conceptions of equality. ${ }^{1}$ And how do we determine what is adequate? To do so, we need some normative understanding of what education is for: Economic independence? Democratic citizenship? Self-actualization? Something else?

The general equality-versus-adequacy debate replicates itself at a more specific level when we focus on the educational

\footnotetext{
* Frank G. Millard Professor of Law, University of Michigan Law School. A very preliminary version of this essay was presented as the 2017 Ken Campbell Lecture on Disability Law and Policy at The Ohio State University. The author was counsel for Petitioners in Fry v. Napoleon Cmty. Sch., 137 S. Ct. 743 (2017), one of the principal cases discussed in this piece, and counsel for amici in Endrew F. v. Douglas County Sch. Dist. RE-1, 137 S. Ct. 988 (2017), the other principal case discussed in this piece. The views expressed here are those of the author only. ${ }^{1}$ See Douglas W. Rae, Equalities 133 (1983).
} 
services provided to students with disabilities. When Congress adopted the Education for All Handicapped Children Act in 1975 (the "EAHCA," the statute now known as the Individuals with Disabilities Education Act, or "IDEA"), it estimated that a million disabled children "were "excluded entirely from the public school system", with millions more "receiving an inappropriate education." 2 The EAHCA required that every child with a disability receive a "free appropriate public education."3 That mandate plainly barred schools from excluding disabled children, but what kind of education was required? What was "appropriate"?

In its earliest case under the EACHA - the Rowley case, decided in 1982 - the Court refused to read the requirement of an "appropriate" education for children with disabilities as guaranteeing that they receive "“equal' educational opportunities." It instead adopted a variant of an adequacy standard: "We therefore conclude that the 'basic floor of opportunity' provided by the Act consists of access to specialized instruction and related services which are individually designed to provide educational benefit to the handicapped child." 5 But the Court declined to "establish any one test for determining the adequacy of educational benefits conferred upon all children covered by the Act."6

In the years since Rowley, at least three developments have pushed education policy generally_and disability education policy specifically - towards a greater focus on equality. First, in 1990, Congress adopted the Americans with Disabilities Act

\footnotetext{
${ }^{2}$ Bd. of Educ. v. Rowley, 458 U.S. 176, 189 (1982) (quoting Act of Nov. 29, 1975, § 3(b)(3), 89 Stat. 774 ("Statement of Legislative Findings and Purpose")).

${ }^{3} 20$ U.S.C. $\$ 1412(a)(1)(2015)$.

${ }^{4}$ Rowley, 458 U.S. at $198-201$.

${ }^{5} I d$. at 201.

${ }^{6} I d$. at 202.
} 
("ADA"), which aimed "to provide a clear and comprehensive national mandate for the elimination of discrimination against individuals with disabilities."7 The ADA applies its requirements of nondiscrimination and reasonable accommodation to every state and local government entity, as well as every seller of goods and services in the United States economy. It thus covers both public and private schools, from pre-kindergarten through graduate school.

Second, in 2002 President George W. Bush signed the No Child Left Behind Act ("NCLB"). Among its many controversial provisions, No Child Left Behind sought to hold states accountable for achievement gaps between demographic groups. The law expressly stated that students with disabilities would presumptively be served in the general education curriculum and be measured by the same achievement standards as their nondisabled peers. ${ }^{8}$

Third, in a series of reauthorizations through the years, Congress amended the IDEA to give added emphasis to the statute's equal opportunity goals. When it reauthorized the statute after the enactment of No Child Left Behind, Congress added provisions that explicitly referred to the results-oriented accountability standards of NCLB. ${ }^{9}$

In light of these developments, a number of scholars and activists urged that the courts should give the IDEA's free appropriate public education requirement a more robust reading than Rowley had placed on it. ${ }^{10}$ The lower courts consistently rebuffed those efforts, however. If anything, they took the law in

\footnotetext{
${ }^{7} 42$ U.S.C. $\S 12101(b)(1)$ (2015).

${ }^{8}$ For a discussion of the NCLB provisions regarding disabled students, see Stephen A. Rosenbaum, Aligning or Maligning? Getting Inside A New IDEA, Getting Behind No Child Left Behind and Getting Outside of It All, 15 Hastings Women's L.J. 1, 26-30 (2004).

${ }^{9}$ See generally Individuals with Disabilities Education Improvement Act of 2004, Pub. L. No. 108446, 118 Stat. 2647 (2004) (codified at 20 U.S.C. $\S \S 1400-1475$ (2015)).

${ }^{10}$ See, e.g., Maureen A. MacFarlane, The Shifting Floor of Educational Opportunity: The Impact
} 
the opposite direction - they read Rowley as holding that virtually any educational benefit received by a disabled student, even an incredibly minimal one, was sufficient to provide a free appropriate public education.

This past Term, the Court revisited Rowley for the first time since that case was decided 35 years earlier. In Endrew F. $v$. Douglas County School District RE-1, ${ }^{11}$ the Court rejected the "merely more than de minimis" test that the Tenth Circuit had applied to determine what educational benefit was sufficient for a free appropriate public education. But it specifically rejected the Petitioner's argument that the IDEA required schools to aim to provide an equal educational opportunity.

By rejecting an equal-opportunity standard for determining compliance with the free appropriate public education requirement, Endrew F., like Rowley before it, responded to the difficulty in specifying equal opportunity in a way that courts can implement. In some respects, I will argue, that decision was understandable and perhaps sensible. But equal opportunity concerns still lie below the surface of the Court's opinion in Endrew F., and they remain a crucial foundation of the IDEA's requirements.

And, exactly one month before it decided Endrew F., the Court made clear that children with disabilities are entitled to an equal educational opportunity. That entitlement rests, not on the IDEA, but on the ADA. In Fry v. Napoleon Community Schools, ${ }^{12}$ the Court held that a disabled child could enforce the ADA's requirements of equal participation in education independently of the IDEA — and could do so without first going through the IDEA's

of Educational Reform on Rowley, 41 J.L. \& Educ. 45, $46-47$ (2012) (citing articles and cases in which this argument was made).

${ }^{11}$ Endrew F. v. Douglas County Sch. Dist. RE-1, 137 S. Ct. 988 (2017).

${ }^{12}$ Fry v. Napoleon Cmty. Sch., 137 S. Ct. 743 (2017). 
complex administrative procedures, so long as she was not seeking relief for the denial of a free appropriate public education. When Fry and Endrew F. are read together, they establish that children with disabilities do have federal rights to equal opportunity in education - but that the ADA, not the IDEA, is the key vehicle for enforcing those rights. The equality right under the ADA is different in important ways from the one that the Endrew F. petitioner asked the Court to read into the IDEA, though.

\section{Endrew F.: The Equality Claim the Court Rejected}

\section{A. The Endrew F. Decision}

When the Court granted certiorari in Endrew F., advocates had high hopes that its decision would give more robust content to the free appropriate public education requirement than it had in Rowley. At the same time, though, they feared that the Court would freeze into place the very lenient standards adopted by the lower courts. In the end, neither advocates' greatest hopes nor their greatest fears were realized.

Endrew F. is an autistic child. ${ }^{13}$ He attended public school in Douglas County, Colorado, from preschool through the fourth grade, pursuant to Individualized Education Programs ("IEPs") drafted for him each year as the IDEA requires. When it came time to draft his fifth grade IEP, however, Endrew's parents believed that a change was necessary. They believed that "his academic and functional progress had essentially stalled: Endrew's IEPs largely carried over the same basic goals and objectives from one year to the next, indicating that he was failing to make meaningful progress toward his aims." 14 When the school district did not agree

\footnotetext{
${ }^{13}$ Facts in this paragraph are taken from the Court's opinion in Endrew F., 137 S. Ct. at 996-997. ${ }^{14} I d$. at 996.
} 
to make any changes to the IEP, Endrew's parents decided to enroll him in a private school for autistic children.

Under longstanding IDEA case law, parents whose disabled children do not receive a free appropriate public education in their local school district are entitled to receive reimbursement of private school tuition from that district. ${ }^{15}$ Accordingly, Endrew's parents filed an administrative complaint under the IDEA seeking tuition reimbursement. (The IDEA requires parents first to file their cases before a state administrative law judge before raising a claim under the statute in court. ${ }^{16}$ ) They argued that the school district had denied Endrew a free appropriate public education, because its IEPs were insufficiently ambitious. But the ALJ disagreed. The parents sought review in federal district court, but that court affirmed the decision, as did the Tenth Circuit Court of Appeals. The appellate court read Rowley "to mean that a child's IEP is adequate as long as it is calculated to confer an 'educational benefit [that is] merely . . . more than de minimis." "17 And it held that the school district had satisfied that standard, because "Endrew's IEP had been 'reasonably calculated to enable [him] to make some progress." "18

The Supreme Court held that the lower courts had applied too lenient a standard. "When all is said and done," the Court explained, "a student offered an educational program providing 'merely more than de minimis' progress from year to year can hardly be said to have been offered an education at all." ${ }^{19}$ It held that "[t]he IDEA demands more. It requires an educational

\footnotetext{
${ }^{15}$ See Forest Grove Sch. Dist. v. T.A., 557 U.S. 230 (2009).

${ }^{16}$ See 20 U.S.C. $\$ 1415$ (2015).

${ }^{17}$ Endrew F., 137 S. Ct. at 997 (quoting Endrew F. ex rel. Joseph F. v. Douglas County Sch. Dist. RE-1, 798 F.3d 1329, 1338 (10th Cir. 2015) (internal quotation marks omitted by Supreme Court)).

${ }^{18}$ Id. (quoting Endrew F., 798 F.3d at 1342 (internal quotation marks omitted by Supreme Court)).

${ }^{19} \mathrm{Id}$. at 1001 .
} 
program reasonably calculated to enable a child to make progress appropriate in light of the child's circumstances." 20

But although both Endrew's parents and various amici argued that the IDEA should be read as imposing an equal-educationalopportunity standard, the Court rejected those arguments. The Court relied entirely on Rowley, which had said that "[ $\mathrm{t}]$ he requirement that States provide 'equal' educational opportunities would . . . seem to present an entirely unworkable standard requiring impossible measurements and comparisons." ${ }^{21}$ The Endrew F. Court concluded that "Congress (despite several intervening amendments to the IDEA) ha[d] not materially changed the statutory definition of a FAPE [a free appropriate public education] since Rowley was decided," and it "decline[d] to interpret the FAPE provision in a manner so plainly at odds with the Court's analysis in that case." 22

\section{B. The Difficulties With an Equality Standard Under the IDEA}

What, precisely, was the equal opportunity standard Endrew's parents proposed? They asked the Court to hold that the IDEA requires " an education that aims to provide a child with a disability opportunities to achieve academic success, attain selfsufficiency, and contribute to society that are substantially equal to the opportunities afforded children without disabilities." 23 It is hardly surprising that the Court refused to adopt this formulation as the standard school districts were required to follow, because every piece of it is vague.

There are several distinct ways of cashing out the idea of

\footnotetext{
${ }^{20} \mathrm{Id}$.

${ }^{21}$ Endrew F., 137 S. Ct. at 1001 (quoting Rowley, 458 U.S. at 198)).

${ }^{22} I d$.

${ }^{23}$ Id. (quoting Brief for Petitioner at 40, Endrew F., 137 S. Ct. 988 (2017) (No. 15-827)).
} 
educational equality. Nearly all of these would be plausibly consistent with the standard proposed by Endrew's parents. Yet each presents significant difficulties.

One way of assessing educational equality is to look to outcomes. To take the terms used by Endrew's parents, perhaps we should say that equality requires that all children achieve a "substantially equal" level of "academic success," "selfsufficiency" or "contribut[ions] to society" as each other. This sort of outcome-oriented equality might make sense when we are focusing on particular basic competencies. As Michael Walzer notes, the job of a teacher of reading is to teach her students to read-not to give them an equal opportunity to learn to read. ${ }^{24}$ But as we focus on broader educational outcomes, the equalachievement goal seems increasingly unreasonable. In any world we can realistically imagine, children will be different, and to expect schools to bring every child to the same level of achievement seems utopian at best, dystopian (the stuff of the Kurt Vonnegut story Harrison Bergeron ${ }^{25}$ ) at worst. ${ }^{26}$

If an equal-achievement standard seems unworkable and extreme, the obvious place to turn is to some notion of equal opportunity. ${ }^{27}$ Every child can't be expected to achieve at the same level, but surely we can give every child the same chance to achieve.

But what does this mean? Perhaps it simply means that we should devote the same resources to each child's education as we

\footnotetext{
${ }^{24}$ Michael Walzer, Spheres of Justice: A Defense of Pluralism and Equality 203 (1983).

${ }^{25}$ Kurt Vonnegut, Harrison Bergeron, in Welcome to the Monkey House 7 (1968).

${ }^{26}$ For a theoretical defense of an equal-outcomes standard in education, see Tammy Harel BenShahar, Equality in Education - Why We Must Go All the Way, 19 Ethical Theory \& Moral Prac. 83 (2016).

${ }^{27}$ For some appropriate skepticism that the distinction between equality of opportunity and equality of result is meaningful normatively, see David A. Strauss, The Illusory Distinction Between Equality of Opportunity and Equality of Result, 34 WM. \& MARY L. REV. 171 (1992). But the distinction is useful for purposes of my discussion.
} 
devote to each other child's education. Christopher Jencks calls this conception of equal opportunity "democratic equality." $28 \mathrm{He}$ dismisses this conception quickly - though he allows that it has the distinct advantage of being more administrable than other instantiations of equal opportunity and thus might be a default that could garner broad support. ${ }^{29}$

As a pure normative matter, the narrow and formal "democratic equality" principle seems quite insufficient. Students will differ from one another for a variety of reasons. As a result, different students will need different resource inputs to learn the same material as their classmates, have the same chance to learn the same material as their classmates, have the same chance to achieve their potential as their classmates, and so forth. If we care about equal educational opportunity because we want to give all children equal chances to learn, then allocating the same resources to each student seems both over- and under-inclusive-it gives some more than they need, and others less.

The problem is particularly acute in the disability context. Accommodations for students with disabilities often cost money. Even if the cost of those accommodations is often exaggeratedas it is-the cost still exists. At least for many students with disabilities, then, the "democratic equality" principle will deny them equal opportunities to learn as are enjoyed by their classmates.

So we need a more robust conception of equal educational opportunity. Responding to the limitations of the input-oriented "democratic equality" view, and the over-ambitiousness of the equal-outcomes view, many advocates have sought to define

\footnotetext{
${ }^{28}$ Christopher Jencks, Whom Must We Treat Equally for Educational Opportunity to be Equal?, 98 Eтнісs 518, 520 (1988).

${ }^{29}$ See id. at 532.
} 
educational equality by reference to a child's potential. In the Rowley case, the lower courts interpreted the EAHCA to require that a disabled child receive "an opportunity to achieve [her] full potential commensurate with the opportunity provided to other children." 30 The Supreme Court, as we have seen, rejected that interpretation, both in Rowley and in Endrew F.

Was the Court wrong to do so? There is something very attractive in saying that the point of public education is to give each child the same opportunity to achieve her potential. But can equal-opportunity-to-achieve-potential work as an operative legal standard that governs decisions regarding what services to give individual children? There are a number of reasons for skepticism.

First, how do we measure a child's potential? When we are deciding what educational interventions to provide a child ex ante, all we can do is predict, based on generalizations that are sure to be overbroad, what developmental path a particular child will take. And when we are judging the sufficiency of those educational interventions ex post, our counterfactuals about what the child would have achieved if she had received different interventions are likely to rely on similarly overbroad generalizations.

Because of the difficulty of prediction, the application of an equal-opportunity-to-achieve-potential standard in practice is likely to turn on-and thus reinforce-existing stereotypes about what individuals with particular diagnoses and conditions can achieve. But, as the Endrew F. Court noted, "[a] focus on the particular child is at the core of the IDEA. The instruction offered must be 'specially designed' to meet a child's 'unique needs' through an '[i]ndividualized education program."'31 Although on-the-ground

\footnotetext{
${ }^{30}$ Rowley, 458 U.S. at 186 (internal quotation marks omitted).

${ }^{31}$ Endrew F., 137 S. Ct. at 999 (quoting 20 U.S.C. $§ \S 1401(29) \&(14)$ (2015)) (emphasis in the Court's opinion)).
} 
practice under the statute does not always live up to this guarantee of individualization, ${ }^{32}$ an effort to focus on an individual child's potential would, perhaps perversely, exacerbate the problem.

Relatedly, making a child's entitlements turn purely on an assessment of that child's potential would provide a ready avenue for stigma and prejudice against disabled children to enter the decisionmaking process - and effectively ratchet down the rights guaranteed by the IDEA. There is a longstanding pattern-among teachers, school administrators, courts, and even sometimes parents - of underestimating the potential of children with disabilities. A legal requirement that is built around an assessment of potential may simply entrench the existing low expectations for disabled children.

Finally, despite its initial appeal, there are serious normative questions about a guarantee that all children should have the same opportunity to achieve their potential. First, even considered in the abstract, it is unclear why one's potential is a normatively valuable referent. Many people are drawn to a potential-maximizing standard based on the casual utilitarian assumption that society benefits when people achieve the most that they can. But a utilitarian would have to consider costs along with those benefits. And once we take costs into account, utilitarianism does not seem to suggest that we should provide children an equal opportunity to achieve their potential. ${ }^{33}$

Consider two children. Emily has the potential to learn to

\footnotetext{
${ }^{32}$ See, e.g., Karen Syma Czapanskiy, Special Kids, Special Parents, Special Education, 47 U. MicH. J.L. REFORM 733, 767 (2014).

${ }^{33}$ The discussion in text assumes that potential is static, or at least is unaffected by our decisions about where to invest educational resources. But if a child's potential is responsive to those investment decisions - such as, if investing resources in children with more potential encourages children to take actions that expand their potential - then the calculus gets even more complicated. For this reason Jencks argues persuasively that a utilitarian approach to equal educational opportunity is indeterminate. See Jencks, supra note 28, at 529.
} 
care for herself, and perhaps to learn to perform certain repetitive tasks, but due to a disability she has no potential to learn to engage in more complex intellectual and social tasks. (Leave aside for a moment the questions of how we know her true potential, and of whether we are underestimating her.) But educating her to her full potential will be cheap and easy; it will require the investment of very few resources.

Felicia, by contrast, has the potential to learn everything Emily can learn, plus the potential to understand and advance knowledge in cutting-edge scientific fields, and the potential to learn to navigate complex social situations. For Felicia to achieve that potential, however, will require an extensive investment of resources-orders of magnitude greater than the investment that is required to enable Emily to achieve her full potential. If we give Emily all the resources she needs, are we bound to give Felicia the many more resources she needs to have a commensurate opportunity to achieve her full potential?

A utilitarian would likely say no. To a utilitarian, the question would be which allocation of marginal resources has the greatest marginal effect on the relevant achievement measure. At the point at which the marginal cost of investing resources in a particular child exceeds the marginal benefit, a utilitarian would say that we should invest additional resources in someone else. So, perhaps at some point Felicia will be able to achieve enough of her potential that the benefits of her achieving more of that potential are less than the cost of the resources that it will take to enable her to make the next leap. And perhaps the marginal benefits of giving Emily the relatively small allocation of resources she needs to achieve her full potential always exceed the marginal costs. If that is right, then perhaps Emily is normatively entitled to more than an equal opportunity to achieve her potential, and Felicia is entitled to less. 
But a utilitarian calculus will not always be beneficial to children with disabilities. If the costs in my hypothetical were flipped, it would be the nondisabled Felicia, rather than the disabled Emily, who would be entitled to a more-than-equal opportunity. Either way, utilitarianism does not seem to offer a persuasive grounding for an equal-opportunity-to-achieve-potential principle.

A focus on potential poses still a deeper problem for egalitarians. Where does potential come from, after all? Potential depends, in the first instance, on the physical and mental attributes with which a child is born (and their degree of compatibility with the physical and social environment in which she is born). But that is, of course, simply a matter of brute luck-the lottery of birth. By the time the child gets to school, her potential will have been significantly affected by the physical, social, and economic environment in which she has been raised for her first few years. That, too, is a matter of luck. Children with higher potential, then, are likely to be children who were lucky enough to have been born and raised in circumstances that increased their potential—and it should not at all surprise us if those children are also the children who experience more socioeconomic advantages generally. A principle that requires us to give every child the same opportunity to achieve his or her potential thus will likely replicate, reinforce, and retransmit existing inequalities. It will, on average, give more to the children who are already more advantaged-reversing those egalitarian principles that enjoin us to give more priority to those who are less advantaged. ${ }^{34}$ One might, therefore, say that

\footnotetext{
${ }^{34}$ See Gina Schouten, Fair Educational Opportunity and the Distribution of Natural Ability: Toward a Prioritarian Principle of Educational Justice, 46 J. PHiL. Educ. 472 (2012); see generally Derek Parfit, Equality and Priority, 10 Ratio 202, 213 (1997) (describing and defending the view that "[b]enefiting people matters more the worse off these people are").
} 
the equal-opportunity-to-achieve-potential rule gets things exactly backwards from an egalitarian perspective-that the state has an obligation to intervene to give more to those children who have less potential, in part because it is the state's failure to intervene earlier that created the social and economic conditions that limited their potential. ${ }^{35}$

In principle, we could try to solve this problem by "purifying" the concept of potential. We could attempt to strip away all of the ways that society — by acting and failing to act—limited a child's ability to achieve, and then require the state to give every child the same opportunity to reach that pure form of potential. Once we strip away all of the social contributions to potential, though, there may be very little left to distinguish among children. This is true even for children with disabilities. It is a basic tenet of the "social model" underlying modern disability rights advocacy that disability is not a condition that is inherent to the physical body of an individual but that it instead results from an interaction between her body and social decisions. ${ }^{36}$ What makes an inability to walk disabling, the argument goes, is not merely the physical condition (say, quadriplegia) that creates the inability, but instead the decisions to create buildings with stairs instead of elevators, to fail to invest in accessible public transit, and so forth.

But if the lion's share of the difference in different children's "potential" results from social decisions, that means that the equal-opportunity-to-achieve-potential principle comes close to collapsing into a requirement of equal outcomes - a requirement

\footnotetext{
${ }_{35}$ Jencks calls this an argument for "strong humane justice," which he finds normatively appealing but impractical to achieve. See Jencks, supra note 27, at 527. Schouten argues that Jencks's principle of "weak humane justice" must be supplemented with a "prioritarian principle of educational justice" to reduce inequalities that result from natural and social disadvantages. See Schouten, supra note 34, at 483-487.

${ }^{36}$ See, e.g., Samuel R. Bagenstos, Subordination, Stigma, and "Disability," 86 VA. L. Rev. 397, 428429 (2000).
} 
we have already determined to be too ambitious. As Jencks says, "if equal opportunity means that children raised in different families must have equal probabilities of success, we can never fully achieve it." 37

\section{A Robust Adequacy Standard Driven by Equality Concerns}

The foregoing discussion should make clear the difficulties in crafting an equal-educational-opportunity standard that both is normatively appealing and can be applied by courts and school districts. In light of these difficulties, it is hardly surprising that Rowley and Endrew F. refused to impose such a standard. But that does not mean that Endrew $F$. disregarded the principles of equal educational opportunity. To the contrary, I submit, the best way to understand the rules adopted by the Court is to see them as a way of implementing equal educational opportunity, without requiring an impractical case-by-case equality analysis.

Endrew $F$. held that " $[\mathrm{w}]$ hen a child is fully integrated in the regular classroom, as the Act prefers, what [meeting the child's unique needs] typically means is providing a level of instruction reasonably calculated to permit advancement through the general curriculum." 38 In his unanimous opinion for the Court, Chief Justice Roberts described the IDEA as an "ambitious" piece of legislation, ${ }^{39}$ and that the educational program provided to a

\footnotetext{
${ }^{37}$ Jencks, supra note 27 , at 527 . John Roemer attempts to address this problem by suggesting that equal educational opportunity cannot be achieved on an individual basis. Rather, he suggests that "the equal-opportunity policy must equalize, in some average sense ... the educational achievements of all types [i.e., social groupings], but not equalize the achievements within types, which differ according to effort." John E. Roemer, Equality of Opportunity 7 (2000). But Debra Satz persuasively suggests that "the equalization of children's potentials (on average) across social types" is not "even plausible as a guiding principle for educational policy, particularly in a society marked by inequalities outside education." Debra Satz, Equality, Adequacy, and Educational Policy, 3 Educ. Fin. \& Pol'y 424, 430 (2008).

${ }^{38}$ Endrew F., 137 S. Ct. at 1000.

${ }^{39} \mathrm{Id}$. at 999.
} 
disabled child must accordingly "be appropriately ambitious." ${ }^{40}$ He explained that the statute's substantive standard must "focus[] on student progress." 41 And he said that "every child should have the chance to meet challenging objectives." 42

This language, combined with the Court's rejection of the merely-more-than-de-minimis standard, imposes a robust adequacy requirement on school districts in their education of disabled children. Understood in the light of the IDEA's strong presumption toward serving children with disabilities alongside nondisabled children ${ }^{43}$ - a presumption to which the Court specifically referred ("as the Act prefers") — that standard significantly advances the equality interests of disabled children.

In the equality-versus-adequacy debate in education policy generally, a number of scholars have argued that adequacy rules are best understood as serving equality. ${ }^{44}$ Debra Satz, for example, emphasizes the importance of an adequate education in promoting civic equality by giving everyone the tools to engage in political self-governance and to earn income in the market. ${ }^{45}$ The robust education required by the Endrew $F$. standard is well suited to preparing individuals with disabilities to engage in these activities. Elizabeth Anderson focuses specifically on the role of educational integration in promoting civic equality. ${ }^{46}$ By recognizing the statute's background preference for integration, Endrew F. fits

\footnotetext{
${ }^{40} \mathrm{Id}$. at 1000 .

${ }^{41} I d$. at 999.

${ }^{42} I d$. at 1000 .

${ }^{43}$ For a discussion of the IDEA's integration presumption, see Samuel R. Bagenstos, Abolish the Integration Presumption? Not Yet, 156 U. PA. L. Rev. PENNumbra 157 (2007).

${ }^{44}$ See, e.g., Joshua E. Weishart, Transcending Equality Versus Adequacy, 66 Stan. L. ReV. 477, 480 (2014); see generally Derrick Darby \& Richard E. Levy, Slaying the Inequality Villain in School Finance: Is the Right to Education the Silver Bullet?, 20 KAN. J.L. \& PuB. PoL'y 351 (2011).

${ }^{45}$ See Satz, supra note 37.

${ }^{46}$ Elizabeth Anderson, Fair Opportunity in Education: A Democratic Equality Perspective, 117 EтHICs 595 (2007).
} 
Anderson's argument well. It also fits Martha Nussbaum's argument that the IDEA serves the interest in equal protection of disabled children by requiring extensive educational interventions to enable those children to enter society as full participants. As Nussbaum argues, even if the statute does not require equal outcomes, it demonstrates equal concern for children with disabilities by insisting on those extensive interventions. ${ }^{47}$

Does Endrew F. adopt an equality standard? Not directly. The Court specifically rejected a test under which a school district's responsibilities to a particular child would depend on an assessment of what would give that child an opportunity that was equal to that enjoyed by her classmates. But the Court adopted a robust adequacy standard that plainly serves the interest in achieving educational equality — and that makes no sense absent an underlying commitment to educational equality. Although Endrew $F$. rejected the parents' equality claim, I submit that it is still best understood as a case about equality.

\section{Fry: The Equality Claim the Court Embraced}

\section{A. The Fry Decision}

On its face, Fry v. Napoleon Community Schools ${ }^{48}$ was not a case about educational equality. Indeed, it was not even a case about the substance of the Individuals with Disabilities Education Act. Rather, the case involved the relationship between the IDEA and other statutes, notably the Americans with Disabilities Act. The question before the court was whether a disabled child could enforce rights under those other statutes without first exhausting the administrative proceedings required by the IDEA. The Court

\footnotetext{
${ }^{47}$ Martha Nussbaum, The Capabilities of People with Cognitive Disabilities, 40 MetaphiLosophy 331, 341-343 (2009).

${ }^{48}$ Fry v. Napoleon Cmty. Sch., 137 S. Ct. 743 (2017).
} 
held that such a child need not go through proceedings under the IDEA so long as the "gravamen" of her suit under another statute "is something other than the denial of the IDEA's core guarantee" of a "free appropriate public education." 49 Although the Court's decision does not embrace any particular substantive standard, it opens the way to meaningful enforcement of an equality principle under the ADA that is very similar to the one the plaintiff in Rowley unsuccessfully sought to interject into the IDEA.

Ehlena Fry (referred to in the Court's decision as "E.F.") has cerebral palsy. ${ }^{50}$ At her doctor's suggestion, Ehlena's parents obtained a service dog for her when she was a young child. The parents chose for the job a goldendoodle (a species that is often used for service animals, because few people are allergic to it). The family named the dog "Wonder." Wonder assisted Ehlena with such activities as "retrieving dropped items, helping her balance when she uses her walker, opening and closing doors, turning on and off lights, helping her take off her coat, [and] helping her transfer to and from the toilet." ${ }_{51}$

When Ehlena enrolled in her local public school's kindergarten, the school refused to allow Wonder to accompany her. Instead, it offered the services of a one-on-one human aide, who would perform all of the tasks that the dog would. When, by the end of the year, the principal decided to stick with the refusal to permit Wonder to work as a service dog, Ehlena's parents pulled her out of school and filed a complaint with the United States Department of Education's Office for Civil Rights. That complaint alleged that the school had violated Ehlena's rights under the ADA by denying

\footnotetext{
${ }^{49} I d$. at 748 .

${ }^{50}$ Facts in this paragraph and the next are taken from the Court's opinion. See Fry, 137 S. Ct. at $750-$ 51.

${ }^{51}$ Id. at 751 (quoting Complaint at $\uparrow 27$, Fry, 137 S. Ct. 743 (No. 15-497)).
} 
her the chance to use her service dog. It did not allege a violation of the IDEA.

School officials defended against the administrative complaint by arguing that "that they [w]ere not required to permit the service animal to accompany and assist [Ehlena], because they [we]re meeting all of [her] educational needs through the provision of an aide." ${ }^{52}$ But the Department of Education rejected the defense and concluded that the school district had violated the ADA. Ehlena alleged a violation of the ADA's requirement that a state or local government entity must provide "reasonable modifications to rules, policies, or practices" where necessary to avoid discrimination on the basis of disability ${ }^{53}$ - a requirement that has long been interpreted to demand that such entities permit disabled users of their facilities to be assisted by service dogs. ${ }^{54}$ Because Ehlena argued that the school had denied her the equal access to its facilities that the ADA guaranteed, rather than that the school had denied her a free appropriate public education, the Department of Education concluded that a "FAPE analysis" was beside the point. ${ }^{55}$ The Department "analogized the school's conduct to 'requir[ing] a student who uses a wheelchair to be carried' by an aide or 'requir[ing] a blind student to be led [around by a] teacher' instead of permitting him to use a guide dog or cane." ${ }^{56}$ Those examples, like the school's denial of a service dog, did not deny a free appropriate public education, but they did violate the ADA "by discriminating against children with disabilities." ${ }^{57}$

The Department of Education ordered the school district to

\footnotetext{
${ }^{52}$ Joint Appx. at 28, Fry, 137 S. Ct. 743 (No. 15-497) (emphasis added).

${ }^{53} 42$ U.S.C. $\$ 12131(2)(2015)$.

${ }^{54} 28$ C.F.R. $\$ 35.136(\mathrm{~g})(2016)$.

${ }_{55}$ Joint Appx. at 35, Fry, 137 S. Ct. 743 (No. 15-497) (emphasis added).

${ }^{56}$ Fry, 137 S. Ct. at 751 (quoting Joint Appx. at 35, Fry, 137 S. Ct. 743 (No. 15-497)).

${ }^{57} \mathrm{Id}$.
} 
readmit Ehlena (who had been homeschooled during the two years during which her complaint was pending) and to permit her to use her service dog. But Ehlena's parents became concerned, after meeting with the principal, that the school would "resent" being required to allow Wonder to attend and, as a result, would make Ehlena's "return to school difficult." 58 They decided to enroll Ehlena in a neighboring district, and to file a lawsuit against her original school for violating the ADA by refusing to allow her to use her service dog. ${ }^{59}$ Because the case focused entirely on the school district's past conduct, and neither Ehlena nor her parents had any desire to re-enroll her in the district, the lawsuit sought only retrospective relief_-damages for Ehlena's emotional distress in being denied the use of her dog and the corresponding ability to participate independently in the classroom. ${ }^{60}$

The lower courts dismissed the ADA suit, because they concluded that Ehlena's parents should first have exhausted administrative remedies under the IDEA. ${ }^{61}$ Unlike the federal Department of Education complaint process in which Ehlena's parents originally pursued their ADA claims, the IDEA's administrative scheme requires parents to proceed before a stateappointed hearing officer or administrative law judge, who will hold a trial-type hearing and issue a decision that will then be subject to judicial review in federal district court. ${ }^{62}$ Although Ehlena's parents did not allege that the school violated the IDEA, the lower courts concluded that exhaustion of the statute's procedures was required anyway, because of a provision Congress added to the IDEA in 1986. That provision, in its current form, reads:

\footnotetext{
${ }^{58} I d$. (internal quotation marks omitted).

${ }^{59} \mathrm{Id}$.

${ }^{60} \mathrm{Id}$. at $751-752$.

${ }^{61} \mathrm{Id}$. at 752 .

${ }^{62} 20$ U.S.C. $\S 1415$ (2015).
} 
Nothing in this chapter shall be construed to restrict or limit the rights, procedures, and remedies available under the Constitution, the Americans with Disabilities Act of 1990, title V of the Rehabilitation Act of 1973, or other Federal laws protecting the rights of children with disabilities, except that before the filing of a civil action under such laws seeking relief that is also available under this subchapter, the [administrative] procedures under [the IDEA] shall be exhausted to the same extent as would be required had the action been brought under this subchapter. ${ }^{63}$

Congress added that provision to overturn the Supreme Court's 1984 decision in Smith v. Robinson. ${ }^{64}$ Smith held that the IDEA implicitly barred disabled children from enforcing education rights under other federal statutes, such as the Rehabilitation Act and Section 1983 ${ }^{65}$ Rejecting Smith, the new text made clear that the IDEA did not foreclose parents from bringing suit under "other Federal laws protecting the rights of children with disabilities." But it required parents first to pursue IDEA remedies if their complaints were ones "seeking relief that is also available under" the IDEA.

The Frys' suit challenged the refusal to permit Ehlena to be accompanied by her service dog - a challenge that would have been essentially identical if Ehlena had been seeking access to a public library or recreation facility rather than a school, and one that would have been identical if a disabled parent had been denied the chance to bring the parent's service dog to watch a child at

\footnotetext{
${ }^{63} 20$ U.S.C. $\S 1415(1)$.

${ }^{64}$ Smith v. Robinson, 468 U.S. 992 (1984).

${ }^{65}$ See id. at 1009-1016.
} 
a school play. The educational setting, and Ehlena's status as a student, thus were simply the occasion for the controversy; they played no substantive role in it. The Frys were seeking relief for a pure ADA violation, not a violation of the IDEA. Moreover, they sought only emotional distress damages - a remedy that is not available under the IDEA. ${ }^{66}$ For these two reasons, they argued that exhaustion of the IDEA processes was not required. But the lower courts read the exhaustion requirement more broadly. Following the overwhelmingly dominant view in the circuits, the Sixth Circuit held that exhaustion of IDEA proceedings was required whenever it appeared possible that those proceedings could provide some remedy for the injuries of which the child complained-even if the remedy was a different one than the child sought in her lawsuit. ${ }^{67}$

The Sixth Circuit's decision conflicted with the Ninth Circuit's 2011 en banc holding in Payne v. Peninsula School District. ${ }^{68}$ In contrast to the "injury-centered" rule employed by the Sixth Circuit and other courts of appeals, Payne adopted what it called a "relief-centered" rule governing IDEA exhaustion: If the relief the plaintiff actually sought was, in form or substance, relief that was available under the IDEA, exhaustion was required; but if the plaintiff did not actually seek relief that was available under the IDEA - even if such relief might have been available - the nonIDEA case could proceed directly to court. ${ }^{69}$

The Supreme Court granted certiorari in Fry, presumably to resolve that conflict. But the Court ultimately punted on the issue. In a footnote, the Court explained that it was "leav[ing] for another

\footnotetext{
${ }^{66}$ Fry, 137 S. Ct. at 752 n.4.

${ }^{67}$ See Fry v. Napoleon Cmty. Sch., 788 F.3d 622, 625 (6th Cir. 2015).

${ }^{68}$ Payne v. Peninsula Sch. Dist., 653 F.3d 863 (9th Cir. 2011) (en banc), cert. denied, 565 U.S. 1196 (2012).

${ }^{69} \mathrm{Id}$. at 874 .
} 
day" the question whether "exhaustion [is] required when the plaintiff complains of the denial of a FAPE, but the specific remedy she requests - here, money damages for emotional distress-is not one that an IDEA hearing officer may award."70 Instead, the Court resolved the case on a more fundamental ground. Regardless of the particular relief the plaintiff requests, the Court unanimously held, exhaustion is not required in a non-IDEA case if the "substance, or gravamen, of the plaintiff's complaint" is not "seek[ing] relief for the denial of a FAPE." is not seeking relief for the denial of a FAPE, the Court held, her complaint is necessarily not "seeking relief that is also available under" the IDEA. ${ }^{72}$

The Court remanded to the lower courts to determine whether the "gravamen" of Fry's complaint was seeking relief for the denial of a FAPE. But Justice Kagan's opinion for the Court offered a couple of guideposts for resolving that question, in Fry and in other cases. The opinion suggested, first, that courts should "ask[] a pair of hypothetical questions" about the complaint:

First, could the plaintiff have brought essentially the same claim if the alleged conduct had occurred at a public facility that was not a school—say, a public theater or library? And second, could an adult at the school—say, an employee or visitor-have pressed essentially the same grievance ${ }^{73}$

"When the answer to those questions is yes," the Court explained, "a complaint that does not expressly allege the denial of

\footnotetext{
$\overline{{ }^{70} \text { Fry, } 137 \text { S. Ct. at } 752}$ n.4.

${ }^{71} \mathrm{Id}$. at 752 .

${ }^{72} \mathrm{Id}$. at 754 .

${ }^{73} \mathrm{Id}$. at 756 .
} 
a FAPE is also unlikely to be truly about that subject; after all, in those other situations there is no FAPE obligation and yet the same basic suit could go forward."74 The Court also said that parents' prior decision to invoke the formal IDEA proceedings to resolve a particular dispute "will often"-_but not always_-"provide strong evidence that the substance of a plaintiff's claim concerns the denial of a FAPE, even if the complaint never explicitly uses that term." 75 Justice Alito, joined by Justice Thomas, joined all of Justice Kagan's opinion for the Court except for the discussion of the guideposts for resolving the gravamen-of-the-complaint question. $^{76}$

\section{B. Fry as an Equality Case}

The Fry decision is important on its own terms. Even as questions remain regarding how the lower courts will interpret the new gravamen-of-the-complaint standard, the decision marks a major shift from prior lower-court cases. In those cases, the courts asked a hypothetical question: Could the plaintiffs have sought any relief for their injuries under the IDEA? Because it is nearly always possible for IDEA proceedings to provide some relief for injuries received at school-even in the form of counseling to address emotional harms - the hypothetical-question approach meant that parents were required to exhaust IDEA administrative proceedings in a wide range of cases that did not at all involve the substance of the educational program, or the choice of educational setting, offered to their children. Cases involving denial of access to service dogs (like Ehlena Fry's suit) and those involving abusive

\footnotetext{
${ }^{74} I d$. at 756 .

${ }^{75} \mathrm{Id}$. at 757 .

${ }^{76}$ Fry, 137 S. Ct. at 759 (Alito, J., concurring in part and concurring in the judgment).
} 
mistreatment of disabled children at school were prime examples. ${ }^{77}$ Most if not all of these cases will now be able to proceed directly to court under the ADA or Section 1983; the plaintiffs will thus be able to avoid burdensome and unavailing IDEA proceedings.

As I have said, nothing in the Fry decision is formally about equality. Fry was a case about administrative exhaustion, not the substantive requirements that apply to schools' treatment of children with disabilities. But the decision has great importance for educational equality. The ADA, unlike the IDEA, formally incorporates an equal-opportunity standard. The state and local government entities covered by the ADA-including public schools - must not discriminate against individuals with disabilities, and they must "make reasonable modifications in policies, practices, or procedures when the modifications are necessary to avoid discrimination on the basis of disability, unless the public entity can demonstrate that making the modifications would fundamentally alter the nature of the service, program, or activity." 78

Ehlena Fry's suit alleged that her school had violated this equal-opportunity standard: By refusing to make a "reasonable modification" to its no-dogs rule to permit her to use her service dog, the school denied Ehlena the same independence that her fellow students had. If her fellow students dropped something, they would not have to ask an adult to pick it up for them. Wonder allowed Ehlena to achieve the same kind of independence. By barring the dog, and requiring her to rely on a one-on-one human

\footnotetext{
${ }^{77}$ See, e.g., Cave v. East Meadow Union Free Sch. Dist., 514 F.3d 240 (2d Cir. 2008) (requiring exhaustion of IDEA proceedings in case alleging refusal to admit service dog); Charlie F. v. Bd. of Educ. of Skokie Sch. Dist. 68, 98 F.3d 989 (7th Cir. 1996) (requiring exhaustion of IDEA proceedings in case alleging that teacher orchestrated disability-based harassment of a fourth grader).

7828 C.F.R. $\S 35.130($ b)(7)(i) (2015).
} 
aide, the school denied her equal independence.

That equality claim was entirely distinct from any possible IDEA claim that Ehlena's education was substantively inadequate and thus denied a FAPE. By making clear that the ADA-based claim could proceed - and could avoid administrative exhaustion if it was sufficiently distinct from an IDEA claim-the Court highlighted the continued significance of the ADA's equality requirements in the education setting.

It is important to appreciate, however, that the ADA's equality requirements are quite different from the equality requirements the Court rejected in Rowley and Endrew F. In those cases, the Court considered whether the IDEA incorporated a requirement that disabled children receive an equal opportunity to achieve certain educational outcomes - notably, to achieve their potential. As I argued above, the equal-opportunity-to-achieve-potential standard is difficult to operationalize and raises troubling normative questions. $^{79}$

But the equality standard as it has been applied under the ADA is more grounded. Rather than asking whether persons with a disability have an equal opportunity to achieve some ultimate outcome, ADA cases focus on whether the refusal to modify a government entity's practices denies disabled persons some more precisely defined opportunity that nondisabled persons receive. For Ehlena Fry, that more precisely defined opportunity was independence in performing physical tasks. But in other education cases the opportunity might touch much more closely on the content of a student's lessons.

Consider the facts of Rowley. Amy Rowley was a deaf student, who asked her school to provide a sign-language interpreter during

\footnotetext{
${ }^{79}$ See supra text accompanying notes $30-37$.
} 
class. The school refused and instead provide her an FM hearing aid. ${ }^{80}$ Even with the hearing aid, she could make out "less than half of what [was] said in the classroom." fellow students, by contrast, could hear essentially everything. The Court concluded that there was no IDEA violation, because she was benefiting sufficiently from the education to "perform[] better than the average child in her class" and "advanc[e] easily from grade to grade." 82 And, as we have seen, the Court rejected the argument that the IDEA required schools to give disabled students an equal opportunity to achieve their potential.

But what if we applied the ADA's equality standard to the facts of Rowley? Just as Ehlena Fry argued that the ADA required her school to permit her to use a service dog so she could have the same opportunity as her nondisabled classmates to be physically independent within the school, a student in Amy Rowley's position could argue today that the ADA requires her school to use a signlanguage interpreter so she can have the same opportunity as her nondisabled classmates to hear the words spoken in the classroom. The interpreter might in fact help provide the student an equal opportunity, vis-à-vis her nondisabled classmates, to achieve her potential, but equal opportunity to achieve potential is not the standard. Equal opportunity to comprehend the words spoken in class is. Applying that equal-opportunity-to-comprehend standard could flip the result in Rowley. ${ }^{83}$

The ADA's equality standard is far more administrable than is the potential-based standard that the Court rejected under the

\footnotetext{
${ }^{80}$ Rowley, 458 U.S. at $184-85$.

${ }^{81}$ Rowley, 458 U.S. at 215 (White, J., dissenting).

${ }^{82}$ Rowley, 458 U.S. at 209-10.

${ }^{83}$ See K.M. ex rel. Bright v. Tustin Unified Sch. Dist., 725 F.3d 1088, 1100-01 (9th Cir. 2013) (holding that hard-of-hearing students could proceed on their ADA claim to require their schools to provide them real-time transcription of class discussions, even though Rowley doomed such a claim under the IDEA), cert. denied, 134 S. Ct. 1493 (2014).
} 
IDEA. Under the ADA standard, the plaintiff needs only to: (1) identify the particular task or benefit that her nondisabled fellow students enjoy but she does not (physical independence, perceiving all of the words in the classroom, etc.); (2) point to a reasonable modification to school rules or policies that would rectify that inequality (a service dog, a sign-language interpreter); and if necessary (3) defend against the school's claim that the modification would be so burdensome as to "fundamentally alter the nature of" the school's activities. ${ }^{84}$ We don't have to guess at what a student's potential is or would be, or at how often other students get to achieve their full potential.

Is the ADA's equality standard normatively attractive? The ADA, of course, has been an incredibly controversial lawand educational accommodations for students with disabilities have been particularly controversial. ${ }^{85}$ We want schools to give everyone the same chance to learn, but resources are limited. At some point, giving to one student takes from another student. What, we might ask, makes disabled students more worthy than others?

Outside of the education context, I have argued that the ADA's accommodation requirement is justified by the systematic disadvantage that society attaches to disability. ${ }^{86}$ When a relatively small change in an institution's practices can keep the institution from contributing to that disadvantage by denying an opportunity to a person with a disability, it is appropriate to require the change. I have argued that this is basically the justification for classic antidiscrimination laws, which—even when they don't mandate

\footnotetext{
${ }^{84} 28$ C.F.R. $§ 35.130($ b)(7)(i) (2015).

${ }^{85}$ See Backlash Against the ADA: Reinterpreting Disability Rights (Linda Hamilton Krieger ed., 2003).

${ }^{86}$ See Samuel R. Bagenstos, “Rational Discrimination,” Accommodation, and the Politics of (Disability) Civil Rights, 89 VA. L. REv. 825 (2003).
} 
reasonable accommodations-require employers and others to bear some costs to avoid contributing to systematic disadvantage. Employers, for example, are barred from discriminating against women and minorities even if customers refuse to be served by them and instead choose to patronize competing businesses. ${ }^{87}$ And employers are barred from discriminating against pregnant women, even if it is "more expensive or less convenient to" give pregnant workers the same accommodations that other employees receive. ${ }^{88}$ We impose these requirements, not to prevent employers from being individually irrational, but to prevent them from contributing to the systematic disadvantage experienced by minorities and women in the workforce.

Inside of the public education context, the normative argument for accommodations to achieve equal opportunity is even stronger. Although there is a robust debate over the purpose of public education, at the core is opportunity for all-to participate in economic and/or civic life. An institution with the mission of providing opportunity is in less of a position to deny accommodations like this than is an institution (like an employer) with the mission of making money. ${ }^{89}$ The equality standard to which Fry opens the way is thus a far more tractable and defensible equality standard than the one Endrew $F$. rejected.

\section{Conclusion: The Equality Question the Court Did Not Ask}

To this point, I have focused on the equality questions in Endrew F. and Fry from the perspective of students with disabilities. I have asked how the Court's decisions in these cases

\footnotetext{
${ }^{87}$ See Fernandez v. Wynn Oil Co., 653 F.2d 1273 (9th Cir. 1981).

${ }^{88}$ See Young v. United Parcel Service, Inc., 135 S. Ct. 1338, 1354 (2015).

${ }^{89}$ See WALZER, supra note 24, at 197-226.
} 
might affect the degree to which disabled students are treated equally to their nondisabled peers along various axes. And I have examined the administrability of, and normative arguments for, the Court's approach to these equality questions. As I show in Part II, the Court in Endrew F. rejected an equality standard for defining a free appropriate public education under the IDEA, but the robust adequacy standard the Court adopted is one that is necessarily based on a broader concern with equality. And, as I show in Part III, the Court in Fry opened the door to the independent application of an equal-opportunity standard under the ADA - a standard that could well reverse the result in the Rowley case. Each of these holdings seems to me quite defensible.

When one takes a different perspective, though, one can see another equality question in the background of these cases-one to which the Court did not explicitly advert, but one that plays an important role in broader debates regarding the education of disabled students. That question is this: Does a special focus on the rights of students with disabilities inherently discriminate against all, or some subset of, nondisabled children?

In Part III.B., I argued that accommodation of students with disabilities is appropriate because of the systematic disadvantage that disabled people experience in our society. But there are, of course, other groups that experience systematic disadvantage. The overlapping categories of poor people, African-Americans, and Latinos are obvious examples. If giving enforceable rights to educational accommodations to disabled children comes at the expense of these groups, we have reason to worry that the IDEA and ADA are impeding equality, at least along some important dimensions. A recent decision by a state trial court in Connecticut seemed to suggest that the IDEA was having just such a troubling effect, by diverting resources from children in poorer school 
districts. ${ }^{90}$ Some years ago, Professors Mark Kelman and Gillian Lester argued that our disability laws, as applied to education, attempted to avoid the difficult tradeoffs that were necessary here by elevating to the status of a "right" something that is more properly understood as a mere redistributive "claim" that should be resolved as part of pluralist political bargaining. ${ }^{91}$ Underlying both of these arguments is the concern that richer, white parents are better able than poorer, minority parents to navigate the disability laws to obtain accommodations for their children. ${ }^{92}$

These are extremely important issues that I cannot resolve in this essay. But there are good reasons for caution before fully accepting the narrative that gains for children with disabilities come at the expense of poor and minority children. For one thing, many poor and minority children themselves have disabilities. Rates of disability are higher in poor communities, for all sorts of unsurprising reasons. ${ }^{93}$ Indeed, some of the strongest supporters of the Education for All Handicapped Children Act- the law that became the IDEA - were established civil rights groups that had traditionally focused on racial equality. In the late 1960s and early 1970s, they saw that many children who were poor and members of racial minority groups were denied access to educational opportunities because school districts labeled those children as disabled. ${ }^{94}$ Those groups thus concluded that any response

\footnotetext{
${ }^{90}$ Connecticut Coal. for Justice in Educ. Funding, Inc. v. Rell, 2016 WL 4922730 at *27-*32 (Conn. Super. Ct. Sept. 7, 2016).

${ }^{91}$ See Mark Kelman \& Gillian Lester, Jumping the Queue: An Inquiry into the Legal Treatment of Students with Learning Disabilities 195-226 (1997). Kelman elaborates on the "right"/“claim" distinction in Mark Kelman, Market Discrimination and Groups, 53 Stan. L. Rev. 833 (2001).

${ }^{92}$ See, e.g., Kelman \& Lester, supra note 91, at 76-78.

${ }^{93}$ For a nice, accessible discussion, see Rebecca Vallas \& Shawn Fremstad, Disability Is a Cause and Consequence of Poverty, TALKPoverTy (Sept. 19, 2014), https://talkpoverty.org/2014/09/19/ disability-cause-consequence-poverty/.

${ }^{94}$ Joseph P. Shapiro, No Pity: People with Disabilities Forging a New Civil Rights Movement 165 166 (1993).
} 
to educational inequality would have to address disability-a conclusion that continues to seem valid today.

Still, there are lingering concerns. There is a longstanding concern that school districts over-identify certain, more stigmatizing, disabilities (notably emotional disturbance and developmental disabilities) among minority children, while overidentify other, less stigmatizing, disabilities (notably autism) among whites. ${ }^{95}$ These disparate patterns of identification can divert minority students into much more limiting and stigmatizing educational programs than are experienced by similarly situated white students. Any effort to promote educational equality must address that problem. It must also address the barriers that poor and working-class parents face in taking advantage of the IDEA or the ADA. ${ }^{96}$ Although there is no particular reason to believe that these barriers are any greater for poor people in the education context than in many others, the IDEA and ADA will not provide true equality until we address them.

The Endrew F. and Fry cases, in other words, represent important steps toward achieving educational inequality. But many key steps remain.

\footnotetext{
${ }^{95}$ Ruth Colker, Disabled Education: A Critical Analysis of the Individuals with Disabilities EducAtion Act 6-8 (2013). For a recent discussion of racial disparities in special education, see Beth Harry \& Janette Klingner, Why Are So Many Minority Students in Special Education? Understanding Race and Disability in Schools (2014).

${ }^{96}$ See Elisa Hyman, Dean Hill Rivkin \& Stephen A. Rosenbaum, How IDEA Fails Families Without Means: Causes and Corrections from the Frontlines of Special Education Lawyering, 20 AM. U. J. Gender Soc. PoL’y \& L. 107 (2011).
} 